\title{
Erratum: Coding and decoding libraries of sequence-defined functional copolymers synthesized via photoligation
}

Nicolas Zydziak, Waldemar Konrad, Florian Feist, Sergii Afonin, Steffen Weidner \& Christopher Barner-Kowollik

Nature Communications 7:13672 doi: 10.1038/ncomms13672 (2016); Published 30 Nov 2016; Updated 23 Dec 2016

Figures 1 and 6 of this Article contain errors that were introduced during the production process. In Fig. 1, the reaction conditions required to convert 1 to $7 \mathbf{d}, 2 \mathrm{e}$ to $9 \mathrm{c}$ and $\mathbf{1 d}$ to $\mathbf{1 0 d}$ should be described by (i) and not (iv). In Fig. 6, the arrow representing the monomer fragment of $448 \mathrm{Da}$ is pointing to the wrong dashed spectral line. The corrected versions of Figs 1 and 6 are shown below as Figs 1 and 2, respectively. 
a<smiles>C=NNC(=O)c1ccc(COc2cccc(C)c2C=O)cc1</smiles><smiles>COC(=O)C(C)(NC(=O)c1ccc(COc2cccc(C)c2C=O)cc1)N1C(=O)C2C3C=CC(O3)C2C1=O</smiles><smiles>Cc1cccc(OCc2ccc(C(=O)NCCOCCN3C(=O)C4C5C=CC(O5)C4C3=O)cc2)c1C=O</smiles><smiles>Cc1cccc(OCc2ccc(C(=O)NCC(C(=O)NCCCCCCO)N3C(=O)C4C5C=CC(O5)C4C3=O)cc2)c1C=O</smiles><smiles>Cc1cccc(OCc2ccc(C(=O)NNC(=O)C(C(=O)NCC34CC5CC(CC(C5)C3)C4)N3C(=O)C4C5C=CC(C5)C4C3=O)cc2)c1C=O</smiles><smiles>O</smiles><smiles>Cc1cccc(OCc2ccc(C(=O)NC(C)C(C(=O)NCc3ccc(F)cc3)C(C)N3C(=O)C4C5C=CC(O5)C4C3=O)cc2)c1C=O</smiles>

b

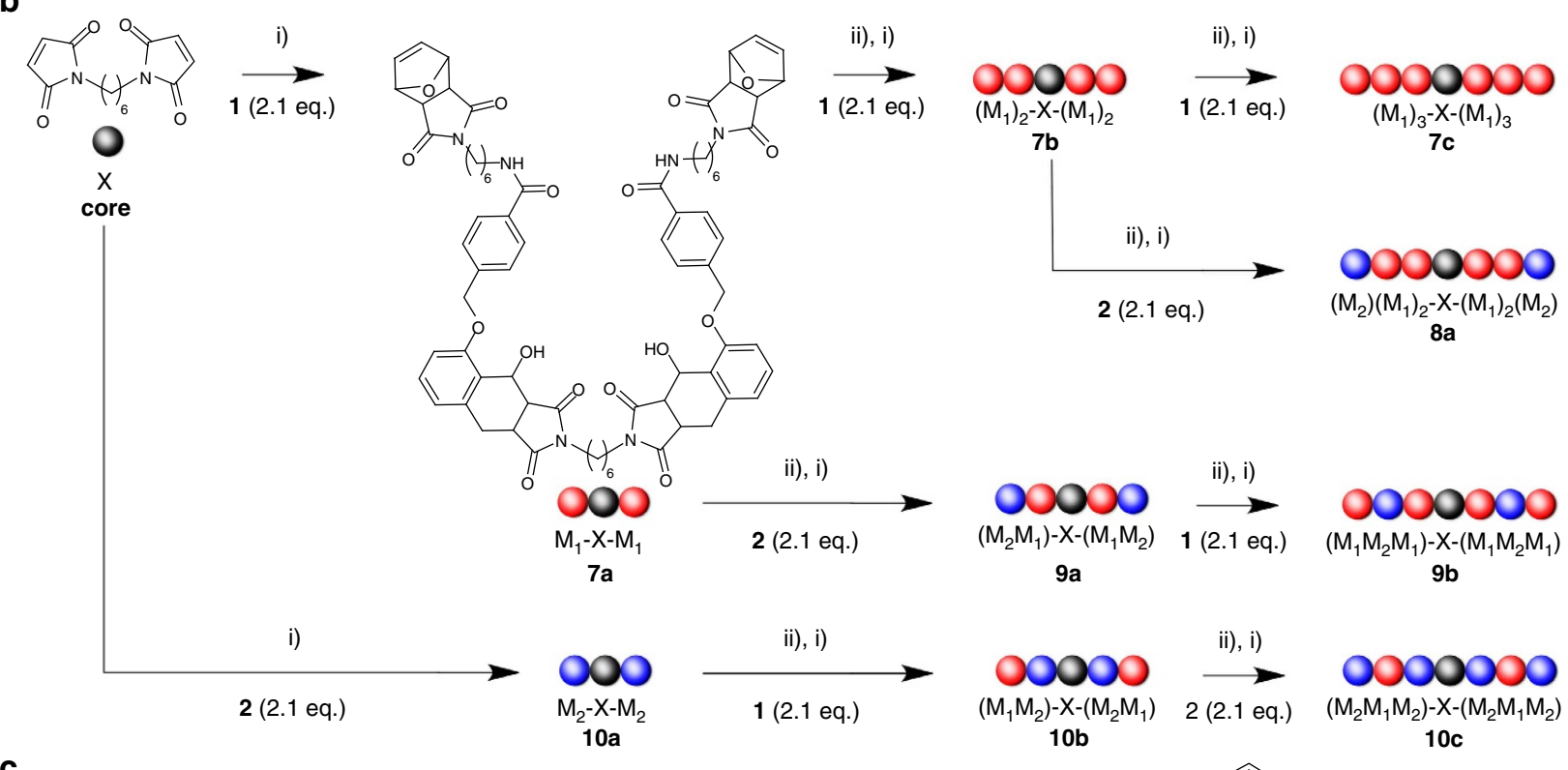

C
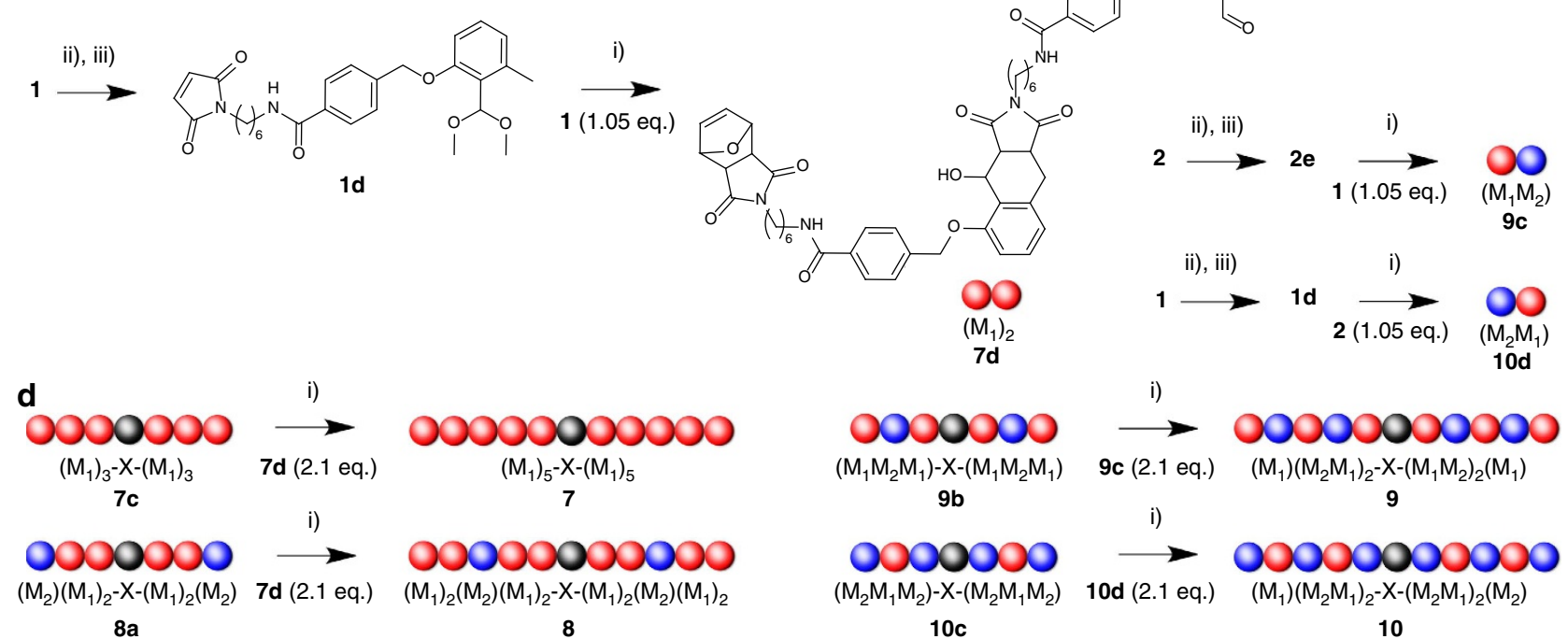

Figure 1. 
a

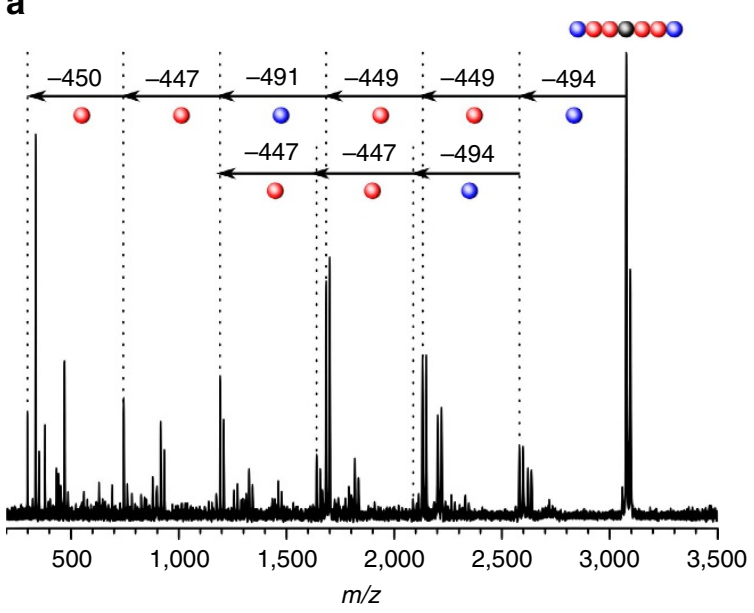

b

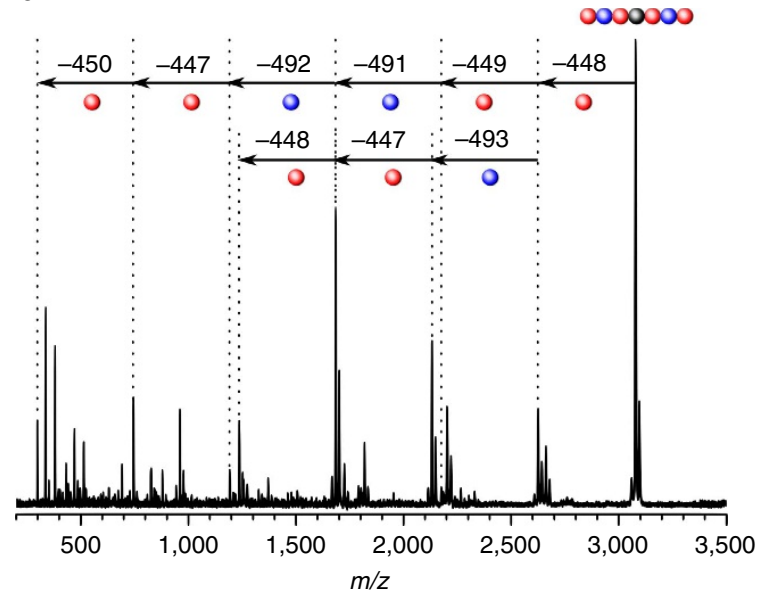

Figure 2.

(c) This work is licensed under a Creative Commons Attribution 4.0 International License. The images or other third party material in this article are included in the article's Creative Commons license, unless indicated otherwise in the credit line; if the material is not included under the Creative Commons license, users will need to obtain permission from the license holder to reproduce the material. To view a copy of this license, visit http://creativecommons.org/licenses/by/4.0/

(C) The Author(s) 2016 